\title{
Hypermethylation of the RUNX3 gene in hepatocellular carcinoma
}

\author{
Won Sang Park ${ }^{1}$, Yong Gu Cho ${ }^{1}$, \\ Chang Jae Kim ${ }^{1}$, Jae Hwi Song ${ }^{1}$, \\ Youn Soo Lee ${ }^{1}$, Su Young Kim ${ }^{1}$, \\ Suk Woo Nam ${ }^{1}$, Sug Hyung Lee ${ }^{1}$, \\ Nam Jin Yoo ${ }^{1}$ and Jung Young Lee ${ }^{1,2}$ \\ ${ }^{1}$ Department of Pathology, College of Medicine \\ The Catholic University of Korea \\ 505 Banpo-dong, Seocho-gu \\ Seoul 137-701, Korea \\ ${ }^{2}$ Corresponding author: Tel, 82-2-590-1190; \\ Fax, 82-2-537-6586; E-mail, stingray@catholic.ac.kr
}

Accepted 27 June 2005

Abbreviation: 5Aza-dC, 5-aza-2-deoxycytidine; cdk, cyclin-dependent kinase; COX-2, cyclooxygenase-2; HCC, hepatocellular carcinoma; TFG- $\beta$, transforming growth factor $-\beta$

\begin{abstract}
Methylation events play a critical role in various cellular processes including regulation of gene transcription and proliferation. Recently, RUNX3 gene, one of TGF- $\beta$-Smads signaling transduction pathway genes, showed strong tumor-suppressor activity by regulation of epithelial proliferation and apoptosis. To elucidate the potential etiological role of the RUNX3 gene in the development of hepatocellular carcinoma (HCC), we have analyzed the methylation status of $5^{\prime} \mathrm{CpG}$ island of the RUNX3 gene in a series of $73 \mathrm{HCC}$ tissues and 11 liver cell lines. Expectedly, promoter methylation of RUNX3 gene was found in $2(2.7 \%)$ of 73 corresponding normal liver, whereas $30(41.1 \%)$ of 73 HCCs and $4(40 \%)$ of 10 liver cancer cell lines showed hypermethylation of the gene, respectively. There was no significant difference between promoter hypermethylaion and clinicopathologic parameters of primary HCC sam ples, including histologic grade, microvascular invasion, and clinical stage. Interestingly, demethylating agent 5-aza-2-deoxycytidine induced reactivation and more potent expression of RUNX3 gene in $\mathrm{HCC}$ cell lines. Our findings indicate that promoter hypermethylation of RUNX3 gene may occur as an early event in the development of HCC and that
\end{abstract}

methylation may be a major mechanism for inactivation of RUNX3 gene in HCC.

Keywords: DNA methylation; epigenesis, genetic; genes, tumor suppressor; liver neoplasms; Runx protein; transforming growth factor- $\beta$

\section{Introduction}

Hepatocellular carcinoma (HCC) is one of the most common causes of cancer death in the world, especially in Asian and African. In Korea, it accounts for an estimated $11.2 \%$ of all malignancies, with $15.4 \%$ in the male population and $6.0 \%$ in the female population (Shin et al., 2004). Thus, HCC remains a significant contributor to the world's health burden. It is well known that heavy alcohol intake and infection with the hepatitis B or C virus are important risk factors for HCC. In addition, numerous genetic abnormalities associated with HCC development have been described. However, little is known about the molecular genetic event in the development and progression of HCC.

TGF- $\beta$ is a multifunctional cytokine known to be a potent growth inhibitor for most epithelial cells (Bissell, 2001; Kloos et al., 2002; Moustakas et al., 2002). TGF- $\beta$-mediated growth arrest occurs by blocking all cycle transits at mid- and late-G1 phases of the cell cycle by inactivation of cyclin-dependent kinases (cdk) and downregulation of c-Myc (Alexandrow and Moses, 1995; Weinberg, 1995). Notably, TGF- $\beta$ receptors and its downstream signal transducer Smads are frequently inactivated in various cancers (Cohen, 2003). Recently, RUNX proteins, including RUNX3, were proved to interact with Smads through their C-terminal segment and recruit Smads to subnuclear sites of active transcription, and exert their biological control (Zaidi et al., 2002). Since RUNX3 is required for the TGF- $\beta$-mediated growth arrest, RUNX3 may be involved induction of CDK inhibitors and/or the Smad-mediated repression of the c-Myc promoter (Bae and Choi, 2004).

Loss of RUNX3 expression through high-frequency hemizygous deletion and hypermethylation was found in $25-75 \%$ of breast, gastric and pancreatic cancers (Li et al., 2002; Kim et al., 2004; Wada et al., 2004). Since RUNX3 is an integral component of the TGF$\beta$-induced signaling pathway, it is possible that RUNX3 may also function as a tumor suppressor of other type 
of cancers where TGF- $\beta$-signaling is impaired. Interestingly, the chromosome 1p36, where RUNX3 resides, is a commonly deleted region in various types of human cancers, including gastric, colorectal, lung, and liver cancers (Weith et al., 1996). Furthermore, introduction of a normal human chromosome 1 p36 into colon carcinoma cells markedly suppressed their tumorigenecity (Tanaka et al., 1993). Recently, epigenetic modification of the RUNX3 gene was found in colorectal cancer cell lines and Chinese HCC (Ku et al., 2004; Xiao and Liu, 2004). All of these findings strongly suggest that the genetic or epigenetic alteration of the RUNX3 gene might be one of possible mechanism disrupting TGF- $\beta$ signaling pathway in HCC.

In this study, to determine whether hypermethylation, reversible epigenetic modification, of the RUNX3 gene be involved in the development of HCC and associated with clinicopathologic parameters including histological grade and clinical stage, we searched the methylation state of the RUNX3 gene in 73 HCCs and 11 liver cell lines.

\section{Materials and Methods}

\section{Samples}

Seventy-three frozen HCCs and their corresponding background liver tissue samples were subjected to this study. Informed consents were obtained from every patient. Ages ranged from 26-89 years with an average of 51.6 years. The male to female ratio was $60: 13$. The background liver showed cirrhosis in 61 $(83.6 \%)$ cases, chronic active hepatitis in $6(8.2 \%)$ cases, chronic persistent hepatitis in $3(4.1 \%)$, and non-specific change in $4(4.1 \%)$ cases. HBV was detected in $64(76.7 \%)$ cases and $\mathrm{HCV}$ was in 5 (6.8\%). Clinically, the cases with histologic grade I, II, and III were 13,26 , and 34 , respectively. One $6 \mu \mathrm{m}$ section stained with hematoxylin and eosin was independently reviewed by three pathologists. In addition, a total of 10 liver tumor cell lines PLC/PRF5, Hep3B, SNU-182, SNU-354, SNU-368, SNU-387, SNU-398, SNU-423, SNU-449, SNU-475 and immortalized normal liver cell line THLE-3 were also included in this study. The cell lines were obtained from ATCC (American Type Culture Collection) or Korean Cell Line Bank (Seoul, Korea). THLE-3 cells, immortalized with SV40 large T antigen, were cultured in bronchial/tracheal epithelial cell growth medium (BEGM ${ }^{\mathbb{R}}$ BulletKit; Cambrex BioScience Walkersville, Walkersville, MD) containing 10\% heatinactivated fetal bovine serum (Life Technologies, Rockville, MD) and antibiotics (100 $\mathrm{U} / \mathrm{ml}$ penicillin and $100 \mathrm{ug} / \mathrm{ml}$ streptomycin). Other cell lines were cultured in RPMI-1640 supplemented with $10 \%$ heat- inactivated fetal bovine serum and antibiotics. Culture plates were maintained in the humidified incubator at $37^{\circ} \mathrm{C}$ with a $5 \% \mathrm{CO}_{2}$ atmosphere. After treatment with $0.05 \%$ trypsin and $0.53 \mathrm{mM}$ EDTA, cells were used for the experiment.

\section{DNA extraction}

Genomic DNA was isolated from frozen HCC tissues and corresponding background liver tissues using a procedure based on the protocol described previously (Goelz et al., 1985). Briefly, the materials were grounded to a fine powder under liquid nitrogen. Ground tissues were incubated overnight in $500 \mu \mathrm{l}$ lytic solution containing proteinase $\mathrm{K}$ at $52^{\circ} \mathrm{C}$. These were followed by extraction with equal volumes of phenol:chloroform:isoamyl alcohol (25:24:1). DNA was ethanol precipitated at $-20^{\circ} \mathrm{C}$, washed with $70 \%$ ethanol, dried and resuspended in $1 \mathrm{X}$ TE buffer. For genomic DNA extraction from each cell line, harvested cells were suspended in lysis buffer containing proteinase $\mathrm{K}$ and DNA was extracted by phenol: chloroform:isoamyl alcohol and ethanol precipitation.

\section{DNA methylation analysis of the RUNX3 gene}

For DNA methylation analysis, sodium bisulfite modification of genomic DNA was performed, as described previously (Grunau et al., 2001; Lehmann et al., 2001; Lee et al., 2004). In brief, $1 \mu \mathrm{g}$ DNA was denatured with $0.2 \mathrm{M} \mathrm{NaOH}$ in a total vol of $50 \mu \mathrm{l}$. After the addition of $350 \mu \mathrm{l}$ of $3.6 \mathrm{M}$ sodium bisulfite containing $1 \mathrm{mM}$ hydroquinone at $\mathrm{pH} 5$, the samples were incubated for $16 \mathrm{~h}$ at $55^{\circ} \mathrm{C}$ in dark. The modified DNA was recovered with $5 \mu \mathrm{l}$ glassmilk (BIO 101, Irvine, $\mathrm{CA}$ ) and $800 \mu \mathrm{l}$ of $6 \mathrm{M} \mathrm{NaCl}$. The glassmilk catching modified DNA was washed three times with $70 \%$ ethanol at room temperature, treated with $0.3 \mathrm{M}$ $\mathrm{NaOH} / 90 \%$ ethanol, and washed twice with $90 \%$ ethanol. The DNA was finally eluted from the dried pellet with $30 \mu \mathrm{l} 1 \mathrm{mM}$ Tris- $\mathrm{HCl}(\mathrm{pH} \mathrm{8.0)}$ for $15 \mathrm{~min}$ at $55^{\circ} \mathrm{C}$. Five $\mu \mathrm{l}$ of bisulfite-modified DNA were subjected to methylation specific PCR (MSP) using two sets of primer specific for methylated and unmethylated DNA, as reported previously (Li et al., 2002). Controls without DNA were performed for each set of PCRs. Ten $\mu$ l of PCR production was directly loaded onto $2 \%$ agarose gels containing ethidium bromide, and directly visualized under UV illumination.

The correlation of the epigenetic alterations with clinicopathologic parameters, including age, sex, virus type, histologic grade, stage, intrahepatic metastasis, portal vein invasion, microvascular invasion, and presence of capsule, was analyzed by Chi Square test and Bartholomew test. 


\section{Demethylating treatment with 5-aza-2-deoxycytidine (5Aza-dC)}

HCC cell lines SNU-368, SNU-387, and SNU-475 were split to low density $\left(5 \times 10^{5}\right.$ per T-25 $\mathrm{cm}^{2}$ flask $)$ $24 \mathrm{~h}$ before treatment and maintained in appropriate media. Cell lines were treated with 5Aza-dC (SigmaAldrich, St. Louis, MO) at a concentration of $5 \mu \mathrm{M}$ for 3 days to achieve demethylation. We isolated RNA using Trizol (Invitrogen, Carlsbad, CA) and reversetranscribed total RNA with M-MLV reverse transcriptase (Invitrogen, Carlsbad, CA). RUNX3 mRNA expression was measured by RT-PCR using RUNX3 specific primers. For $R U N X 3$, the primers were 5'-ACTGTGATGGCAGGCAATGAC-3' and 5'-AATGGGTTCAGTTCCGAGGTG-3'. $\beta$-actin mRNA was also amplified in the same PCR reactions as an internal control using the following primers; 5'-CATGTTTGAGACCTTCAACAC-3' and 5'-CTGCTTGCTGATCCACATCT$3^{\prime}$. The PCR amplification cycles consisted of denaturation at $95^{\circ} \mathrm{C}$ for $3 \mathrm{~min} ; 30$ cycles of denaturation at $95^{\circ} \mathrm{C}$ for $30 \mathrm{sec}$, annealing at $63^{\circ} \mathrm{C}$ for $30 \mathrm{sec}$ and extension at $72^{\circ} \mathrm{C}$ for $30 \mathrm{sec}$, and a final elongation at $72^{\circ} \mathrm{C}$ for $10 \mathrm{~min}$. Ten $\mu$ l of PCR production was directly loaded onto $2 \%$ agarose gels containing ethidium bromide, and directly visualized under UV illumination.

\section{Results}

Frequent hypermethylation of RUNX3 gene in HCC tissues and cell lines

We examined the promoter hypermethylation of the RUNX3 gene using two sets of primers specific for MSP on bisulfite modified DNA, as previously reported (Li et al., 2002). In corresponding normal liver tissues, unmethylated DNA of the RUNX3 gene was amplified in all 73 samples and methylated DNA was also amplified in two cases with cirrhotic background. Expectedly, hypermethylation was found in 30 $(41.1 \%)$ of 73 HCC tumor tissues (Table 1 ) and 27 $(90 \%)$ of them showed both methylated and unmethylated DNA PCR products (Figure 1A). The other three cases demonstrated only methylated DNA PCR products. One of the cases with unmethylated and methylated DNAs in corresponding normal tissues showed only methylated DNA PCR products in tumor tissue and the other did both unmethylated and methylated DNA PCR products. Statistically, there was no significant relationship between hypermethylation and clinicopathological parameters, including tumor size, hepatitis virus type, histologic grade, and clinical stage.

Table 1. Correlation of promoter hypermethylation of RUNX3 gene with clinicopathologic parameters.

\begin{tabular}{|c|c|c|c|c|c|}
\hline Parameters & $\mathrm{N}$ & Methylation & Parameters & $\mathrm{N}$ & Methylation \\
\hline Sex & & & Intrahepatic metastasis & & \\
\hline Female & 13 & $5(38.5 \%)$ & + & 13 & $6(46.1 \%)$ \\
\hline Male & 60 & $25(41.7 \%)$ & - & $\begin{array}{l}13 \\
60\end{array}$ & $\begin{array}{r}6(46.1 \%) \\
24(40.0 \%)\end{array}$ \\
\hline Age & & & Portal vein Invasion & & \\
\hline$>60 \mathrm{yrs}$ & 17 & $5(29.4 \%)$ & + & 9 & $3(33.3 \%)$ \\
\hline$<60$ yrs & 56 & $25(44.6 \%)$ & - & 64 & $27(42.2 \%)$ \\
\hline Virus type & & & Tumor size & & \\
\hline Non-V & 4 & $1(25.0 \%)$ & $<3 \mathrm{~cm}$ & 31 & $11(35.5 \%)$ \\
\hline HBV & 64 & $27(42.2 \%)$ & $>3 \mathrm{~cm}$ & 42 & $19(45.2 \%)$ \\
\hline $\mathrm{HCV}$ & 5 & $2(40.0 \%)$ & & & \\
\hline Grade $^{\dagger}$ & & & Tumor capsule & & \\
\hline 1 & 13 & $4(30.8 \%)$ & + & 41 & $17(41.5 \%)$ \\
\hline II & 26 & $13(50.0 \%)$ & - & 32 & $13(40.6 \%)$ \\
\hline III & 34 & $13(38.2 \%)$ & & & \\
\hline Stage & & & Background & & \\
\hline I & 11 & $4(36.4 \%)$ & Cirrhosis & 61 & $26(42.6 \%)$ \\
\hline II & 31 & $13(41.9 \%)$ & $\mathrm{CAH}$ & 6 & $2(33.3 \%)$ \\
\hline III & 24 & $11(45.8 \%)$ & $\mathrm{CPH}$ & 3 & $1(33.3 \%)$ \\
\hline IV & 7 & $2(28.6 \%)$ & Non-specific & 3 & $1(33.3 \%)$ \\
\hline \multicolumn{6}{|l|}{$\begin{array}{l}\text { Microvascular } \\
\text { Invasion }\end{array}$} \\
\hline+ & 35 & $13(37.1 \%)$ & & & \\
\hline- & 38 & $17(44.7 \%)$ & & & \\
\hline
\end{tabular}


A

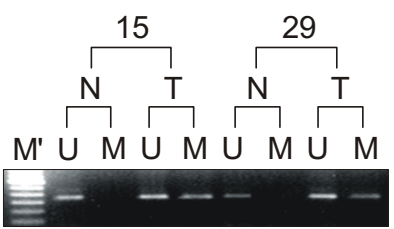

B

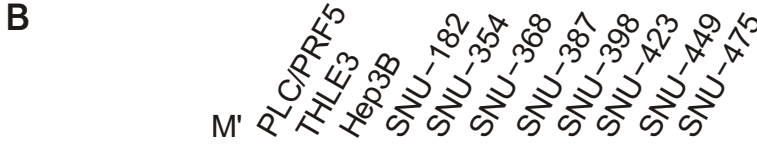

Unmethylated

刲ーーーーーーーーーー

Methylated

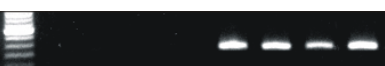

C

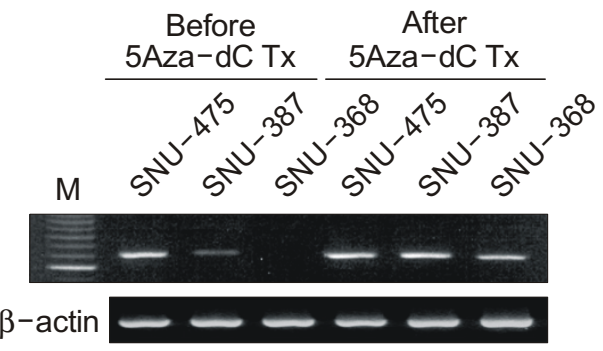

Additionally, we also analyzed promoter hypermethylation in one immortalized normal liver cell line (THLE-3) and 10 liver cancer cell lines. All of the cell lines except SNU-368 amplified unmethylated DNA fragment. However, 4 HCC cell lines, SNU-354, SNU387 , and SNU-398, showed also methylated DNA PCR products and SNU-368 showed only methylated RUNX3 DNA (Figure 1B).

\section{Reactivation of RUNX3 expression by 5-Aza-dC}

To investigate whether RUNX3 mRNA was reexpressed after 5-Aza-dC treatment, HCC cell lines SNU-368, SNU-387, and SNU-475 were treated with the demethylating chemical, 5-Aza-dC, and measured the expression of the RUNX3 gene by RT-PCR. Interestingly, 5-Aza-dC reactivated silenced RUNX3 gene in SNU-368 cell line and restored to high levels in SNU387 cell line (Figure 1C).

\section{Discussion}

Hypermethylation is a regional event that occurs frequently in GC-rich sequence, called $\mathrm{CpG}$ islands and often located within the $5^{\prime}$ regulatory nontranscribed regions of genes. It has been recognized that aberrant hypermethylation of $\mathrm{CpG}$ islands in the promoters of certain tumor suppressor genes is known to
Figure 1. Hypermethylation of the RUNX3 gene in HCC. (A) Representative MSP results of the gene from HCC tissues. Corresponding background liver tissues showed only unmethylated PCR products, whereas HCC tissues demonstrated both unmethylated and methylated PCR products. The numbers at the top represent the case number. (B) All of the cell lines except SNU-368 amplified unmethylated DNA fragment and $4 \mathrm{HCC}$ cell lines, SNU-354, SNU-368, SNU-387, and SNU-398, showed methylated DNA PCR product. The numbers at the top represent the name of cell lines. $(C)$ The effect of 5 Aza-dC on HCC cell lines, SNU-475, SNU-387, and SNU-368. 5Aza-dC treatment resulted in reactivation of the RUNX3 gene in SNU-368 cell line and more potent expression of the gene in SNU-387 cell line. However, SNU-475 containing only unmethylated RUNX3 DNA revealed no effect of $5 \mathrm{Aza}$-dC treatment. $\beta$-actin was also amplified as an internal control. M', 50 bp molecular marker; N, normal DNA; T, tumor DNA; $\mathrm{U}$, results of unmethylated primer; $\mathrm{M}$, methylated primer.

be associated with transcriptional inactivation and loss of function and that promoter hypermethylation is often an early event in multistep carcinogenesis (Toyota and Issa, 1999; Toyota et al., 1999). In HCC, methylation associated silencing has been reported in some genes, including APC, GSTP1, p16, COX-2 and $E$-cadherin, which are involved in hepatocarcinogenesis (Lee et al., 2003).

Recent analyses have revealed that RUNX family members play important roles in both normal developmental processes and carcinogenesis. Interestingly, deletion of the RUNX3 locus in mice resulted in hyperplasia of the gastric epithelium due to the stimulation of proliferation and suppression of apoptosis that was accompanied by a reduced sensitivity to TGF- $\beta 1$. In primary human gastric cancers, RUNX3 is frequently inactivated by gene silencing due to promoter hypermethylation ( $\mathrm{Li}$ et al., 2002). In the present study, we analyzed the promoter hypermethylation of $R U N X 3$ gene in primary HCC tissues and liver cancer cell lines. Expectedly, we found similar incidence of promoter hypermethylation in $41.1 \%(30 / 73)$ and $40 \%(4 / 10)$ of HCC tissues and cell lines, respectively (Table 1 and Figure 1). Statistically, there was no relationship between hypermethylation and clinicopathologic parameters, including tumor size, viral infection, histologic grade, and clinical stage, In addition, 5-Aza-dC, demethylating drug, was able to reactivate and increase the ex- 
pression of the RUNX3 gene in HCC cell lines (Figure 1). These results suggest that promoter hypermethylation of RUNX3 gene may contribute to the development of $\mathrm{HCC}$, as an early event.

Alterations of TGF- $\beta$-Smad signaling pathway are frequent pro-tumorigenic molecular change and have been documented in a wide variety of human cancer (Weiser, 2001). Since TGF- $\beta$ is a central inhibitory factor for non-neoplastic hepatocyte, it is likely that inactivation of TGF- $\beta$-Smad signaling pathway may contribute to the development of HCC. It has also been reported that Runt domain transcription factors are important targets of TGF- $\beta$ signaling and Cterminus of RUNX3 physically interact with SMAD that mediates transmission of TGF- $\beta$ induced growth inhibitory signals to the nucleus (Zhang and Derynck, 2000). Surprisingly, loss of function as evidenced by mutations or deletions of the TGF- $\beta$ pathway genes was rarely present in HCC (Schutte et al., 1996; Kawate et al., 1999; Kawate et al., 2001). Thus, we hypothesized that RUNX3 gene may be a candidate gene of TGF- $\beta$ pathway genes inactivated by methylation in HCC. Recently, Xiao and Liu (2004) have reported no mutation and frequent hypermethylation $(48.4 \%)$ of the RUNX3 gene in HCC tissues. Taken together, the high prevalence of RUNX3 promoter hypermethylation observed in this study and reactivation of expression of RUNX3 by demethylating drug further indicate that promoter region methylation appear to be the dominant mode of inactivation of RUNX3 gene in human HCC and that inactivation of $R U N X 3$ gene might be one of the important causes of TGF- $\beta$-Smad signaling pathway disruption in HCC.

Recently, several studies have demonstrated expression of RUNX3 in the gastrointestinal organs of the developing embryo. Hypermethylation of RUNX3 promoter was frequently found in gastrointestinal cancers, including stomach, liver, colon and pancreas, and our results are entirely consistent with these studies (Bae and Choi, 2004; Kim et al., 2004; Wada et al., 2004). Thus, we concluded that RUNX3 has played an important role in controlling the growth and differentiation of foregut epithelial cells and that RUNX3 inactivation by promoter methylation is a common event in tumors of a foregut derivative.

In summary, we have demonstrated a high frequency of promoter hypermethylation of the RUNX3 gene in HCC tissues and cell lines. These observations provide evidences that promoter hypermethylation may be the major mechanisms for inactivation of RUNX3 gene in HCC. Therefore, inactivation of its function, resulting in impairment of TGF- $\beta$-Smads signaling pathway and of other tumor suppressor function, may contribute to the development and/or progression of HCC, as an early event.
In addition, because RUNX3 is inactivated by DNA methylation, a reversible epigenetic modification, RUNX3 might be a good target of anticancer therapies in HCC patients.

\section{Acknowledgement}

This work was supported by grant (R01-2004-00010463) from Basic Research Program of the Korea Science \& Engineering Foundation.

\section{References}

Alexandrow MG, Moses HL. Transforming growth factor beta 1 inhibits mouse keratinocytes late in $\mathrm{G} 1$ independent of effects on gene transcription. Cancer Res 1995;55:1452-7

Bae SC, Choi JK. Tumor suppressor activity of RUNX3. Oncogene 2004; 23:4336-40

Bissell DM. Chronic liver injury, TGF- $\beta$ and cancer. Exp Mol Med 2001;33:179-90

Cohen MM Jr. TGF beta/Smad signaling system and its pathologic correlates. Am J Med Genet 2003;116A:1-10

Goelz SE, Hamilton SR, Vogelstein B. Purification of DNA from formaldehyde fixed and paraffin embedded human tissue. Biochem Biophys Res Commun 1985;130:118-26

Grunau C, Clark SJ, Rosenthal A. Bisulfite genomic sequencing: systematic investigation of critical experimental parameters. Nucleic Acids Res 2001;29:e65-5

Kawate S, Ohwada S, Hamada K, Koyama T, Takenoshita S, Morishita Y, Hagiwara K. Mutational analysis of the Smad6 and Smad7 genes in hepatocellular carcinoma. Int $\mathrm{J}$ Mol Med 2001;8:49-52

Kawate S, Takenoshita S, Ohwada S, Mogi A, Fukusato T, Makita $F$, Kuwano $H$, Morishita $Y$. Mutation analysis of transforming growth factor beta type II receptor, Smad2, and Smad4 in hepatocellular carcinoma. Int J Oncol 1999;14: 127-31

Kim TY, Lee HJ, Hwang KS, Lee M, Kim JW, Bang YJ, Kang $\mathrm{GH}$. Methylation of RUNX3 in various types of human cancers and premalignant stages of gastric carcinoma. Lab Invest 2004;84: 479-84

Kloos DU, Choi C, Wingender E. The TGF-beta--Smad network: introducing bioinformatic tools. Trends Genet 2002; 18:96-103

Ku JL, Kang SB, Shin YK, Kang HC, Hong SH, Kim IJ, Shin JH, Han IO, Park JG. Promoter hypermethylation downregulates RUNX3 gene expression in colorectal cancer cell lines. Oncogene 2004;23:6736-42

Lee JK, Kim MJ, Hong SP, Hong SD. Inactivation patterns of p16/INK4A in oral squamous cell carcinomas. Exp Mol Med 2004;36:165-71

Lee S, Lee HJ, Kim JH, Lee HS, Jang JJ, Kang GH. Aberrant CpG island hypermethylation along multistep hepatocarcinogenesis. Am J Pathol 2003;163:1371-78 
Lehmann U, Hasemeier B, Lilischkis R, Kreipe H. Quantitative analysis of promoter hypermethylation in laser-microdissected archival specimens. Lab Invest 2001;81:635-7

Li QL, Ito K, Sakaura C, Fukamachi H, Inoue KI, Chi XZ, Lee KY, Nomura S, Lee CW, Han SB, Kim HM, Kim WJ, Yamamoto $\mathrm{H}$, Yamashita $\mathrm{N}$, Yano $\mathrm{T}$, Ikeda $\mathrm{T}$, Itohara $\mathrm{S}$, Inazawa J, Abe T, Hagiwara A, Yamagishi H, Ooe A, Kaneda A, Sugimura T, Ushijima T, Bae SC, Ito Y. Causal relationship between the loss of RUNX3 expression and gastric cancer. Cell 2002;109:113-24

Moustakas A, Pardali K, Gaal A, Heldin C. Mechanisms of TGF-beta signaling in regulation of cell growth and differentiation. Immunol Lett 2002;82:85-91

Schutte M, Hruban RH, Hedrick L, Cho KR, Nadasdy GM, Weinstein CL, Bova GS, Isaacc WB, Cairns P, Nawroz H, Sidransky D, Casero RA, Meltzer PS, Hahn SA, Kern SE. DPC4 gene in various tumor types. Cancer Res 1996;56: 2527-30

Shin HR, Jung KW, Won YJ, Park JG. 139 KCCR-affiliated Hospitals. 2002 annual report of the Korea central cancer registry: Based on registered data from 139 hospitals. Cancer Research and Treatment 2004;36:103-14

Tanaka K, Yanoshita R, Konishi M, Oshimura M, Maeda Y, Mori T, Miyaki M. Suppression of tumourigenicity in human colon carcinoma cells by introduction of normal chromosome 1 p36 region. Oncogene 1993;8:2253-8

Toyota M, Ahuja N, Ohe-Toyota M, Herman JG, Baylin SB, Issa JP. CpG island methylator phenotype in colorectal can- cer. Proc Natl Acad Sci USA 1999;96:8681-6

Toyota M, Issa JP. CpG island methylator phenotypes in aging and cancer. Semin Cancer Biol 1999;9:349-57

Wada M, Yazumi S, Takaishi S, Hasegawa K, Sawada M, Tanaka H, Ida H, Sakakura C, Ito K, Ito Y, Chiba T. Frequent loss of RUNX3 gene expression in human bile duct and pancreatic cancer cell lines. Oncogene 2004;23:2401-7

Weinberg RA. The retinoblastoma protein and cell cycle control. Cell 1995;81:323-30

Weiser R. The transforming growth factor-beta signaling pathway in tumorigenesis. Curr Opin Oncol 2001;13:70-7

Weith A, Brodeur GM, Bruns GA, Matise TC, Mischke D, Nizetic D, Seldin MF, van Roy N, Vance J. Report of the second international workshop on human chromosome 1 mapping 1995. Cytogenet Cell Genet 1996;72:114-44

Xiao W-H, Liu W-W. Hemizygous deletion and hypermethylation of RUNX3 gene in hepatocellular carcinoma. World J Gastroenterol 2004;10:376-80

Zaidi SK, Sullivan AJ, Wijnen AJV, Stein JL, Stein GS, Lian JB. Integration of Runx and Smad regulatory signals at transcriptionally active subnuclear sites. Proc Natl Acad Sci USA 2002;99:8048-53

Zhang Y, Derynck R. Transcriptional regulation of the transforming growth factor-beta-inducible mouse germ line $\mathrm{lg}$ alpha constant region gene by functional corporation of Smad, CREB, and AML family members. J Biol Chem 2000; 275:16979-85 